resulting from slower methods. Electricity and the internal combustion engine have the great advantage that they are little less economical for a small job than for a large one. The small farmer need be neither inefficient nor a drudge ; he can be technically competent and provided with labour-saving implements.

In the past, the financing of the farm and the buying and selling of the produce have been major difficulties in the life of the peasant. The moneylender and the middleman-whether they were one and the same or different individuals-have often made the peasants' life a burden. Marketing of produce has always been a wasteful procedure; the bulky material has been sold to a middleman and the small stuff taken by the women to market and there sold for whatever it would fetch-a timeconsuming operation which, however, was very sociable and clearly enjoyed by the women. These and many other difficulties can be got over by cooperation, and I am firmly of opinion that the only hope of successful establishment of peasant holdings lies in the development of a strong cooperative movement. The Horace Plunkett Foundation in Great Britain is a mine of information on the subject; Denmark can show actual working models, and indeed most of the occupied countries have some experience with it. Co-operative societies can not only buy for the peasant, finance useful operations and warn severely against useless ones ; they can also take over the peasants' products, grade and process them, pack them properly and sell them through expert: salesmen who know the best markets and can obtain the highest prices. They can thus assure to the peusant the maximum return for his labour.

The experience of Denmark shows how well cooperation can flourish in an educated community. Education is absolutely essential ; not simply technical education, but, what is even more important, the moral education that teaches a man to pull his weight and play the game; to accept his full share of responsibility for the community, doing the right thing because it is right and not simply because he fears he might otherwise be caught. In addition to agricultural schools, the Danes early set up 'Folk High Schools' to give this moral training to awaken intelligence and idealism; they were Christian, national institutions and they helped to form an industrious, honest, competent farming community composed of extremely hard-working people, producing commodities of high quality and enjoying a standard of life that was the envy of most of Europe. The Danish small farm expresses the ideal at which many of the leaders of the occupied countries are looking with longing eyes, hoping that when their long night of agony is ended there may dawn a brighter day for themselves and their children.

We, too, shall have our part to play. In his extremely interesting "Life" of Marlborough, Mr. Churchill shows how in the seventeenth and eighteenth centuries Great Britain twice saved Europe by heading the Allied Nations against a power seeking to dominate the whole Continent. Twice the war was won, but twice the peace was lost because we withdrew too soon. Modern history has made the lesson more emphatic; nations cannot live in isolation. On all grounds-economic, political and moral-we must in the reconstruction of Europe render all possible help and continue to play our part in the years of peace to which the nations are looking forward with such ardent longing.

\section{EDUCATION IN THE BRITISH ARMY}

\author{
BY LIEUT. T. H. HAWKINS
}

$T$ WO and a half years ago the British Army education scheme as we know it to-day was officially launched as the "greatest experiment in adult education that has been undertaken in this country". During its period of growth the scheme has come in for a great deal of publicity, adverse and otherwise. A review of its progress may be of use in helping to assess its value as an indication of the way in which adult education is likely to develop in Great Britain in future years.

In the months preceding the outbreak of war the Workers Educational Association and the Y.M.C.A., in consultation with the Board of Education, had convinced the War Office that educational opportunities of a general character, apart from any classes and lectures which form part of military training, should be provided for the young militiamen during their six months compulsory training. To meet the potential demands for lecturers, the universities enlarged their extra-mural boards ad hoc by adding to the representation of the voluntary bodies concerned and began to lay plans for their active participation in the scheme. War came, and these ad hoc committees were dispersed.

But the demand for education could not be ignored. In the early part of 1940, the initiative of the various voluntary organizations connected with adult education led to a widely representative conference at which the setting up of a Central Advisory Council for Adult Education in H.M. Forces was decided upon. In due course the universities, local education authorities and voluntary organizations for adult education appointed members, the three Services nominating observer representatives. The vicechancellors of universities and principals of university colleges were invited to call conferences in their areas, for the purpose of establishing regional committees through which the Central Advisory Council might work. Thus the civilian educational resources were mobilized and placed at the disposal of the Services.

Later a committee met under Sir Robert Haining to consider means whereby the Army's own resources for lecturing and teaching, as well as organization and administration, might be established. (Here it may be noted that, at the outbreak of war, the personnel of the Army Educational Corps of the Regular Army were transferred to operational roles, for the discharge of which in France they were officially commended by Lord Gort in his dispatches.) The report of the Haining Committee appeared in August 1940 , and it is from that date that the scheme as it now exists may be said to have had its birth.

A directorate of Army education was established, the first director being Mr. F. W. D. Bendall, who was seconded from the Board of Education. The Army Education Corps was gradually strengthened, both by the return of its regular peace-time personnel and by the inclusion of new members from the wartime Army.

The objects of the scheme can be briefly stated : (1) maintaining the men and women of the Army in good heart and morale by the provision of educational activities which could be pursued in their off-duty hours ; (2) improving the military efficiency of the fighting services directly by the sharpening of mental 
faculties through constant stimulation and indirectly by the elimination of boredom ; (3) the provision of incentives and opportunities so that men and women should be given every chance of pursuing their peacetime occupations in preparation for their return to civilian life.

Those who had been appointed to implement this scheme were now charged with making themselves worthy of it. The first task lay in promoting publicity, and, from the beginning, the co-operation of the troops was invited by asking them to submit posters to illustrate the facilities offered by the Army education authorities.

By February 1941 the provision of educational facilities for men and women in the Forces was going steadily ahead, although many soldiers in communications to the Press still complained that in their units educational activities were non-existent. But in spite of lectures postponed and courses interrupted by operational duties, even at that time an average of some four thousand lectures and three thousand classes were taking place each month. Most of the lectures and classes were taken by civilians, but in many cases Service men and women with specialist qualifications gave their support.

It must be realized that the successful operation of an educational programme under war conditions was not an easy task. Apart from the difficulties of administration, organization and accommodation, many lecturers found to their great surprise that lecturing to troop audiences was not quite the same as to, say, a W.E.A. audience. Men and women in the Forces form a representative sample of the entire population, and their attitudes to education were as varied as one would expect from such a heterogeneous group. For many soldiers 'education' was but a means of sending them to school again with the implication that they were 'dunces'. Some wore the smile of incredulity; others were afraid of being made to look small and had the marked fear and distrust of budding educationists, which is such a characteristic 'hang-over' 'of their school-days for so many. Further, a fair proportion of the soldiers are quite inarticulate, while others regard any attempts at discussion as personal disparagements of their characters. (May not one concrete aim of education in the futúre be to train men in argument so that, although differing violently from their fellows, they part on friendly terms? This is probably even more necessary for women than men.)

Despite all the difficulties, however, the war-time scheme gained momentum. In order to make the fullest use of unit resources and to train regimental instructors, short courses primarily designed to give basic training in citizenship, knowledge in international affairs and in the methods of instruction, and the running of discussion groups were instituted. For units stationed in towns and villages, the accommodation problems were eased by civilian co-operation, arrangements being made whereby small classes were able to meet in private houses on certain evenings. In some cases buildings were requisitioned and converted into Army study clubs and were used for diverse activities. Most of the educational activities, however, were still being carried out in the uncongenial surroundings of barrack-rooms. To meet this situation the Army Council authorized the provision of quiet rooms for educational studies, and to-day the appearance of, and educational activity in, a unit 'quiet room' is often a guide to the military efficiency of the unit.
With the development of 'academic' pursuits other activities began to emerge. Soon, all the practical classes which one associates with a modern technical college were in operation in some unit or other. These were either conducted in adjacent technical institutes or, in some cases, at neighbouring works when the employees were off duty. (One engineering firm held very successful classes in motor engineering for troops on Sundays.) Practical classes have grown apace and now the 'hobbies and handicrafts room' is one of the show-places in many units.

Music for the Forces has been greeted with enthusiasm similar to that which has revealed itself all over Great Britain during the last four years. Each Command has a full-time E.N.S.A. music adviser; the growth of music clubs in units has been such that these advisers must be rated as among the most hard-worked people in the Army.

So the story unfolds. Interest in the fine arts has been nourished and is bearing sound fruit. Fullest possible use has been made of visual education, and touring pictorial exhibitions have become a common feature of the educational scheme.

Nor have the Army authorities been negligent in developing new methods in education: in many units where facilities for seeing newspapers and hearing broadcast news are poor, 'wall newspapers' have been produced and have become a most effective method of stimulating and maintaining interest in current events as well as providing information about local affairs. From these 'wall newspapers' to the provision of separate information rooms was not a far flight, and these have now become well-established features of Army education.

To meet the demands of troops in units that are constantly on the move, correspondence courses were introduced. These consist of vocational courses, covering nearly all the examinations for the recognized professions, and postal study courses, including those subjects which might conveniently be described as catering for the academic examinations, including pre-matriculation. The initial problems that were raised by the inauguration of such a tremendous scheme have now been ironed out, and many of the more serious students admit their indebtedness to the correspondence scheme. Between September 1941 and March 1943 there were 22,000 enrolments for vocational correspondence courses and 14,300 for postal study courses. In passing, it should be mentioned that this is the only educational activity for which a small fee is charged, the sum of $10 \mathrm{~s}$. being charged in order to exclude those who were likely to fall at the sight of the first hurdle.

The work of the Army Education Corps in hospitals deserves special notice. One soldier in hospital means that the fighting efficiency of his unit and of his country has been reduced. In co-operation with the Royal Army Medical Corps, the Army Education Corps has promoted educational activities in military hospitals designed to return the man as quickly as possible to his military duties. Occupational therapy remained the charge of the medical authorities, while the educational instructors were given the task of promoting educational pursuits of a miscellaneous nature which would provide the patient with diversional occupations and speed his recovery and return to duty. These miscellaneous activities are too numerous to mention, but it can be confidently asserted that Army education has made an important contribution to adult education in its hospital scheme. When the full story is told, it is incumbent 
on all adult educationists to make themselves fully conversant with it.

From the foregoing it can be seen that the programme for education in the war-time Army is very comprehensive and has been tackled with ardour and enthusiasm despite desperately discouraging circumstances. Yet until September 1941 the men charged with operating this programme were keenly aware that they were achieving only a small part of their objective. The voluntary nature of the scheme meant that the educational facilities available were being used only by those people who would normally be engaged in some form of educational pursuit in their peace-time occupations, estimated at about 20 per cent of the whole. The other 80 per cent remained the hard core who displayed little interest and yet included most of the men for whom some form of education was greatly to be desired and who stood in greatest need.

To meet this need a measure of compulsion was necessary. This was first provided in September 1941, when the Army Bureau of Current Affairs was introduced. An official order was issued asking commanding officers to make arrangements for all the personnel on their establishments to be given instruction in current events for one hour each week during training hours. This hour was introduced in order that soldiers might keep abreast of current affairs and so know the purpose behind their duty. In order to surmount the difficulty of shortage of specialist instructors, it was decided that the scheme should be administered by regimental officers. Each officer was charged with carrying out the Army Bureau of Current Affairs hour in his particular platoon or section. As an aid the Army Bureau of Current Affairs issues. him with a brief each week on which to base his talk. These briefs are of two kinds and appear alternately. One, called "Current Affairs", aims at providing a background of knowledge against which current events can be assessed and understood. The other, "War", aims at providing a picture for the soldier of what is happening in the various theatres of war. The most important issue raised by the introduction of the Army Bureau of Current Affairs, however, was the expressed statement that each talk should form the basis of discussion and that all soldiers should be given opportunities to air their opinions freely, however far-fetched and unsubstantiated they might be. There is little need to dwell on the success of this scheme. It is enough to say that the Army Bureau of Current Affairs to-day is recognized as an integral part of Army life. Its establishment has undoubtedly assisted in promoting better relations between all ranks as well as in the maintenance of morale by disseminating facts about the high purpose of our cause.

It must be made clear that the introduction of the Army Bureau of Current Affairs did not mean the discontinuance of other educational activities. Far from it. These continued to flourish and were considerably extended by the compulsory nature of the Bureau. By last autumn Army education had made such progress that the Army Council agreed to introduce compulsion for other educational work. Accordingly a scheme was drawn up designed to be carried out during the period November 1942February 1943. At least three hours per week were to be allotted from training or working hours to education. It was suggested that three hours should be used in the following manner :

(a) One period to be devoted to educating the man as a soldier, for example, by providing instruction in map-reading, message writing, etc.

(b) One period to the education of the man as an individual. In this period men were to be encouraged to pursue subjects of their own choosing.

(c) The other period to be concerned with the education of the man as a citizen. This period is devoted to talks and discussions on the British mode of life, its institutions and methods of government, the British Commonwealth of Nations and British relations with the other members of the United Nations. To cover the citizenship period, monthly directives were issued and met with a very favourable reception.

This scheme has now come to an end and, where commanding officers have lent their support, has achieved considerable success. The citizenship period, in particular, has contributed so much to Army life that the War Office has decided that it shall continue, based on other topics, over the next few months at least.

"The greatest experiment in adult education" is a fitting description of such a gigantic scheme. But even this is only a prelude to the tremendous educational operations which must inevitably be introduced when victory comes and we are faced with the problems of demobilization. We can never be over-prepared. The place of science in this scheme was outlined in the columns of NaTuRE of Augast 16, 1942, p. 173, and a letter from Dr. Basil Yeaxlee in NATURE of September 6,1942 , p. 288 . It is hoped to discuss it more fully at a later date.

\section{INDIGENOUS MALARIA IN GREAT BRITAIN}

\section{By SIR ARTHUR MACNALTY, K.C.B.}

$\mathrm{D}^{\mathrm{R}}$ R. WILLARD C. RAPPLEYE, of Columbia University, has recently issued a warning that after the War the United States will probably be faced with the risk of epidemics of malaria, brought about by the return of malarial patients who have served in the Middle East and other theatres of war where the disease prevails.

In the United States, malaria has progressively diminished in extent and severity during the past eighty years. From Now England, where it once prevailed extensively, it has gradually disappeared, and in Philadelphia and along the valleys of the Delaware and Schuylkill Rivers, formerly hot-beds of malaria, the disease has become much more restricted. In Baltimore a few cases occur in the autumn, but the majority of the patients come from outlying districts and one or two of the inlets of Chesapeake Bay. Throughout the Southern States there are many regions in which malaria prevails; but here, too, the disease has diminished in prevalence and intensity. In temperate regions, like the central Atlantic States, there are only a few cases in the spring and a large number of cases in the autumn. In the Northwestern States malaria is almost unknown. It is rare on the Pacific coast, and in the region of the Great Lakes it prevails only in the Lake Erie and Lake St. Clair regions.

The introduction of fresh foci of infection from abroad would obviously be inimical to this favourable picture, and a similar danger to that foreshadowed by Dr. Rappleye faced Great Britain in the War of 